\title{
THE DILEMMA OF ONLINE LEARNING DURING THE COVID-19: CHALLENGES OR OPPORTUNITIES?
}

\author{
Ira Irzawati \\ irairzawati@gmail.com \\ English Education Study Program, Universitas Katolik Musi Charitas, \\ Palembang, Indonesia
}

\begin{abstract}
This research aimed to investigate the chalenges and opportunities of online leaming system implementation from students' perspectives. In this survey research, 143 students of a private university were involved as the respondents. The respondents were third, fifth, and seventh-semester students from four different departments that have experienced leaming English through an online learning system. The data of the research were gathered through administering an online survey to the respondents. The survey questionnaire covered items related to demographic information, online learning application, and chalenges and opportunities of online learning. The data of the survey were analyzed by presenting the frequency of students' responses towards each item of the questionnaire in form of a percentage. The students believed that online learning potentialy provided both chalenges and opportunities to the students. Technical issues, minimum interaction, bw discipline, and a less effective karning atmosphere were among the dominant chalenges of online leaming. Meanwhile, various material access, flexbility, interactive karning, and a relaxing learning atmo sphere were the major opportunities of online learning. Anticipating the chalenges and maximizing the opportunities are alternative solutions to promote the successful implementation of onine kaming.
\end{abstract}

\section{Keywords: Online Learning, Challenges, Opportunities.}

\section{INTRODUCTION}

The Covid-19 pandemic aris has a farreaching effect on the education field (Huber \& Helm, 2020). It shifted the educational system from classroom to online learning. Selecting online learning as an altemative way to resume education is inevitable because educational institutions around the globe are closed to halt the spreading of Covid-19 (Adnan \& Anwar, 2020).

Online learning is a learning system that is mediated by the Internet (Rapanta, et, al., 2020). It is viewed as a core learning system during this pandemic (Bączek, et, al., 2021). This learning system is bridging communication and interaction among educators and students, especialy at the higher education level. It facilitates teaching and learning activities that are not possibly conducted face to face due to the pandemic outbreak.

The implementation of an online leaming system plays an essential role during this pandemic. It not only helps the learning providers to manage, plan, deliver, and track the process of teaching and karning but also aids the instructors, schools, and universities to facilitate student learning in the period of the educational institution closure (Almaiah, Al-Khasawneh, \& Althunibat, 2020).

The successful implementation of a leaming system relies on various factors. Chalenges and opportunities are among the factors that require to take into account. The data related to 


\section{ESTEEM JOURNAL OF ENGLISH STUDY PROGRAMME \\ P-ISSN 2622-9323 E-ISSN 2622-2213}

chalenges and opportunities are highly beneficial to provide fruitful insights for developing the learning system. Minimizing the chalenges and maximizing the opportunities are keys to supporting the earning system implementation success.

Numerous studies examined the benefits and drawbacks of integrating an online leaming system (Almaiah, Al-Khasawneh, \& Althunibat, 2020; Al-Qahtani, 2019; Appana, 2008, Jingyu, 2014; Sadeghi, 2019). However, the previous studies only concern with examining students' perspectives at certain levels and majors. This study investigated students' perspectives on chalenges and opportunities of online karning through involing various levels and majors of the students.

\section{LITERATURE REVIEW}

\section{a) Overview of Online Learning}

The best kaming system has been a part of debate topics for decades. Several scholars argue that online learning is better than classroom learning. Meanwhile, others suggest that classroom karning is less effective than online leaming.

Alsaaty, Carter, Abrahams, \& Alshameri, (2016) stated that the effectiveness of online learning versus classroom learning are classified into four categories: (1) both online learning and classroom karning are equaly effective from an educational standpoint, (2) the superiority of online karning mode relative to classroom learning mode, (3) the superiority of classroom leaming mode relative to onne leaming mode,

(4) the superiority of hybrid learning system namely the combination between online leaming and classroom kaming.

Online leaming refers to a leaming experience or environment that relies upon the use of the internet as the main delivery mode in presentation and communication (Appana, 2008). It is a type of teaching and learning that requires the teachers and leamers to conduct teaching and learning activities virtualy. In addition, the materials and communication accesses entail technology support (Anderson, 2011).

Jingyu (2014) asserted that the implementation of online learning cause pros and cons both from students and lecturers. For instance, in terms of flexibility, students and lecturers agreed that the fexibility of online learning brings benefits and limitations. From the students' perspectives, fexibility assists the students to accommodate tasks, control leaming, and study at their own pace. Yet, $\mathbf{t}$ requires more self-motivation, organization, and panning than classroom karning. Meanwhile, the lecturers believed that online learning provides a time and place independent environment for teaching schedule. However, the time for teaching an onine course is greater than classroom kaming.

\section{b) Review of Online Learning Studies}

Since the emergence of online learning, numerous studies have been conducted to investigate various issues related to the learning system.

In 2020, Almaiah, Al-Khasawneh, \& Althunibat explored the critical chalenges and factors influencing the E-leaming system usage during the COVID-19 pandemic. The respondents of this study were 30 students and 31 experts from universities in Jordan and Saudi Arabia. Based on the findings, $t$ was figured out that technology, e-learning system quality, and culture, self-efficacy, and trust are the critical factors that affect the usage of e-learning systems. In addition, three main chalenges that impede the usage of e-learning systems are change management, technical issue, and financial support problems.

Appana (2008) presented a review of the benefits and limitations of online learning in the context of the student, the instructor, and the tenured faculty. The researcher concluded that increased access, improved leaming quality, better preparation of students for a knowledgebased society, leaming opportunities are the potential benefits of online leaming. Vice versa, online learning start-up funding, organizational preparedness, and student readiness are the major mitations of onine leaming.

Another research that examined online learning was conducted by Sadeghi in 2019. The results of this study revealed the advantages and disadvantages of conducting online learning. The advantages of online leaming cover flexible time and place, affordable cost, no commuting, free choice, time efficiency, muliple activities. 


\section{ESTEEM JOURNAL OF ENGLISH STUDY PROGRAMME \\ P-ISSN 2622-9323 E-ISSN 2622-2213}

Meanwhile, the disadvantages of online learning include high distraction, complicated technology, no social interaction, and less interaction with tutors.

The other study was conducted by AtQahtani in 2019. This research focused on investigating teachers' and students' perceptions towards the applications of online learning. The results showed that both teachers and students agreed that online learning has advantages and disadvantages. The students stated that a comfortable environment, easy leaming process, effort and time saving and various materials are the main advantages of online leaming. Meanwhile, technical problems and lack of facial expressions are the most dominant disadvantages of online learning. In line with it, the teachers mentioned motivating teaching environment, effective time management, and technological tool integration, and time and place flexbility are the advantages of online leaming. Whereas, technical problems, needs for extra training, and lack of student control are the disadvantages of onine leaming.

\section{c) Advantages Versus Disadvantages of Online Learning}

According to Arkorful \& Abaidoo (2014), The utilization of online learning systems provides advantages and disadvantages. Several advantages of online leaming include: (1) flexible time and place as the students have the privilege to manage their time and place, (2) knowledge enhancement due to the easy access of huge amount of information, (3) interactive discussion forum to build communication and relation, (4) costeffective and no commuting, (5) individual learner differences consideration, (6) self-pacing in leaming for eachindividual.

In line with it, some disadvantages of implementing an online learning system cover: (1) lack of interaction with the lecturer, (2) less effectiveness compare to classroom learning dealing material explanation, (3) potential negative effect to communication skil, (4) less control of any cheating act during examination, (5) plagiarism exposure due to the ease of copypaste, (6) limited institutions' socialization role and lecturers' instructor's role, (7) unsuitable for al types of major, (8) highly cost due to the heavy use of websites.

\section{METHODOLOGY}

The researcher used survey design as $t$ alows the researcher to scan a wide field of issues, populations, and programs to assess or present any generalized feature (Cohen, Manion \& Morrison, 2000). In this study, the survey design was employed to investigate the chalenges and opportunities of online leaming system implementation from the students' perspectives.

One hundred and forty-three students voluntarily participated as respondents of this study. The students were third, fifth, and seventh-semester students that experienced online leaming for at least one semester. The students also were from four different departments, namely Accounting, Management, Primary School Teacher Education, and English Education Study Program.

The researcher administered an online survey in the form of a close-ended and openended questionnaire to colect the data. The questionnaire comprised three main sections. The first section deals with demographic information that helps the researcher to identify the level, major, gender, pre-pandemic online learning experience, and $\Pi T$ skils of the students. The next section focuses on finding out students' perspectives on online learning. The last section provides questionnaire items that facilitate the researcher to examine students' perspectives related to chalenges and opportunities of online learning. The questionnaire was adapted from a questionnaire written by Bączek, et., al. (2021).

The data of the survey were analyzed by presenting the frequency of students' responses towards each item of the questionnaire in form of a percentage. The high and smal number of percentages assisted the researcher to portrait students' perspectives toward the implementation, chalenges, and opportunities of onine kaming.

\section{RESULTS AND DISCUSSION}

\section{a) Results of Survey}

Student Profile 


\section{ESTEEM JOURNAL OF ENGLISH STUDY PROGRAMME \\ P-ISSN 2622-9323 E-ISSN 2622-2213}

Out of one hundred forty-three students that responded to the questionnaire where $60.1 \%$ of the respondents were third-semester students, $18.2 \%$ were fifth-semester students, and the rest $21.7 \%$ were seventh-semester students. Furthermore, the respondents were from four different departments, namely, Accounting $(29.4 \%)$, Primary School Teacher Education $(28.6 \%)$, Management (28\%), and English Education (14\%). In addition, $62.9 \%$ of the respondents were male and $37.1 \%$ of them were female.

Concerning online learning, $74.1 \%$ of the respondents mentioned that they ever joined online learning before the Covid-19 pandemic. Vice versa, $25.9 \%$ of the respondents stated that they never experienced online leaming. The respondents added that they had proper $\Pi T$ skils to participate in online karning. In terms of $I T$ skil mastery, the respondents classified their skils into three categories where $88.1 \%$ of the students were in the moderate category, $8.4 \%$ of the students were in the bw category, and 3.5\% of the students were in the high category.

\section{Implementation of Online Learning}

The results of the questionnaire on students' perspectives towards the implementation of online leaming are presented in Table 1.

\section{Table 1 Students' Perspectives on Online Learning}

\begin{tabular}{clcc}
\hline No & \multicolumn{1}{c}{ Statement } & A & D \\
\hline 1 & Communication & $60.1 \%$ & $39.9 \%$ \\
\hline 2 & Motivation & $86.7 \%$ & $13.3 \%$ \\
\hline 3 & Effectiveness & $89.5 \%$ & $10.5 \%$ \\
\hline 4 & Easiness & $79.7 \%$ & $20.3 \%$ \\
\hline
\end{tabular}

Pertaining to the implementation of online learning, the students generaly perceived $t$ positively. The responses of the students were classified into four main categories, namely, communication, motivation, effectiveness, and easiness.

Dealing with communication, $60.1 \%$ of students agreed that online learning facilitated communication between students and lecturers. Meanwhile, $39.9 \%$ of the students disagreed that online learning provided effective communication, especialy between lecturers and students.

In relation to motivation, most of the students $(86.7 \%)$ of the students expressed their agreement with the statement that online learning motivated them to leam better. Vice versa, some of the students (13.3\%) showed their disagreement with the statement. The students believed that online learning didn't necessarily elevate their kaming motivation.

Regarding the effectiveness, around $89.5 \%$ of students agreed that was effective to learn English virtualy. However, $10.5 \%$ of the students showed different opinions, leaming English through an online system was not effective to support the leaming activities.

Finaly, many students $(79.7 \%)$ believed that $\mathbf{t}$ was easy to leam English in virtual class but, some students $(20,3 \%)$ disagreed with the statement. Studying in the classroom is simpler than leaming in the virtualclass.

\section{Challenges of Online Learning}

The students' opinions related to chalenges that were potentialy occurred through online learning are described in Figure 1.

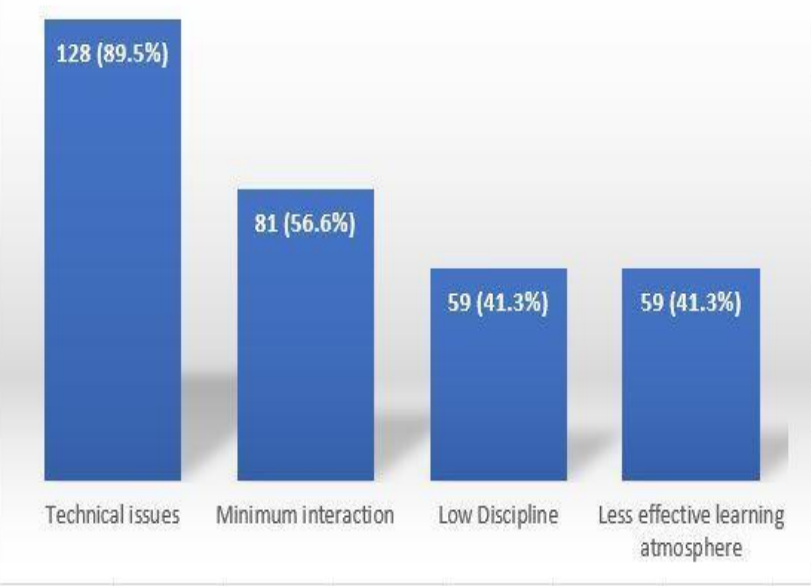

Figure 1 Challenges of Online Learning

As the other types of leaming systems, the implementation of online learning brought chalenges to the students. Technical issues, minimum interaction, bw discipline, and a less effective learning atmosphere are the main chalenges encountered by the students.

In detail, most of the students (89.5\%) stated that technical issues are the major barriers 


\section{ESTEEM JOURNAL OF ENGLISH STUDY PROGRAMME \\ P-ISSN 2622-9323 E-ISSN 2622-2213}

during online teaching and leaming activities. For instance, slow internet connection due to bad weather caused students unable to folow the class. As the consequence, the students missed the important points and did not grasp the materials wel.

The next chalenge is minimum interaction. $56.6 \%$ of the students said that online learning did not alow active interactions between students wth their friends or students with their lecturers. It was chalenging for the students to interact with the lecturer for asking more questions or explanation.

Low discipline is another chalenge faced by the students during online leaming. The core of online leaming was the student-centered approach. The students are required to have high discipline in managing schedules, doing tasks, etc. Besides, there was no ful control from lecturers during the eaming process. Thus, for almost haf of the students (41.3\%), t caused low discipline awareness of the students that lead to another chalenge.

The same number of students $(41.3 \%)$ added that online learning created a less effective learning atmosphere. Technical problems and limited interaction are among the major factors that contribute to the occurrence of this chalenge.

\section{Opportunities of Online Learning}

The students believed that online learning provided many opportunities. The responses of the students are ilustrated in Figure 2.

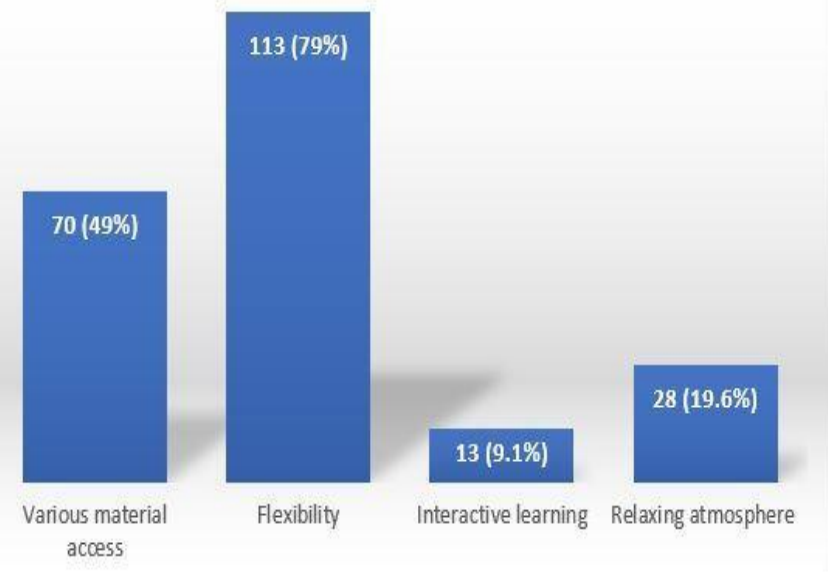

Figure 2 Opportunities of Online Learning
Online karning not ony brings chalenges but also opportunities. Some of the opportunities included various material access, flexibility, a relaxing atmosphere, and interactive leaming.

For most of the students (79\%), flexbility is the main opportunity gained from online learning. It was possible for the students to manage their time wel. The students did not need to come to campus and attend the class. They were able to study from their house or anywhere.

As stated by around $49 \%$ of the students, various material access is another opportunity found in online karning. Online karning enabled the students to access various materials for learning in any form. A large number of materials helped the students to understand the learning material better and obtain more knowledge related to the discussed topics.

Another opportunity is a relaxing atmosphere. Some students $(19,6 \%)$ mentioned that online learning facilitated them to experience a relaxing atmosphere. Since the communication was indirect and through the internet, t helped them to anticipate anxiety to interact directly with the lecturers.

Around $9,1 \%$ of the students confirmed that interactive leaming is the other opportunity provided by online karning. Learning activities were fun due to the use of technological devices as media and various karning materials that assisted them to enjoy the leaming process.

\section{b) Discussion}

The fndings revealed that the students' perspectives towards the implementation of online learning were positive. The students believed that the implementation of online learning has brought positive impacts dealing with communication, motivation, effectiveness, and easiness. This implied that online karning was one of the potential leaming systems to support the teaching and learning process, especialy during the Covid19 pandemic.

In conjunction wth $\mathbf{t}_{\text {, }}$ online learning provided both chalenges and opportunities for the students. The students mentioned that technical issues, minimum interaction, bw discipline, and a less effective kaming 


\section{ESTEEM JOURNAL OF ENGLISH STUDY PROGRAMME \\ P-ISSN 2622-9323 E-ISSN 2622-2213}

atmosphere were among the most dominant chalenges encountered during the online learning process. These chalenges were possibly anticipated wth the assistance of authorities, institutions, lecturers, students, and parents. For instance, the authorities are able to provide free internet access for lecturers and students and encourage the providers to improve their internet connection. Lecturers are able to apply more appropriate kaming strategies and design learning activities that promote maximum interaction, elevate students' discipline awareness and create a more effective learning atmosphere. In short, participation from al parties is required to support the successful implementation of onine kaming.

Flexibility, various material access, a relaxing atmosphere, and interactive karning are the opportunities provided by online leaming. It is important to maintain and develop these opportunities so that $\mathbf{t}$ brings positive impacts especialy to the achievement of the students. Creating more opportunities enables the students to gain a better understanding and achievement in learning. A great number of the students believed that flexbility and various material access are the biggest opportunities for online learning. However, only a smal number of the students considered a relaxing atmosphere and

\section{ACKNOWLEDGEMENT}

The researcher would like to express her profound gratitude to the UKMC community for the support and high appreciation to the research participants for their participation and cooperation

\section{REFERENCES}

Adnan, M. \& Anwar, K. (2020). Online learning amid the COVID-19 pandemic: Students' perspectives. Journal of Pedagogical Sociology and Psychology. 2(1), 45-51.

Almaiah, M., A., Al-Khasawneh, A., \& Althunibat, A. (2020). Expbring the critical chalenges and factors influencing the E-learning system usage during COVID-19 pandemic. Education and Information Technologies, 25, 5261-5280.

Alsaaty, F., M., Carter, E., Abrahams, D., \& interactive leaming as opportunities for online learning. It also requires efforts from al related parties to maximize the potential impacts of the two opportunities or create more new opportunities to bring many positive impacts, especialy to students. For example, lecturers are able to use various media or games to build a more relaxing and interactive learning atmosphere for the students.

The fndings of this research offer useful suggestions particularly to authorities, institutions, and educators to anticipate the potential chalenges and promote the probable opportunities for successful online karning system integration.

\section{v. CONCLUSION}

On the basis of findings and discussion, $t$ was found that students perceived the implementation of online leaming positively. However, this type of leaming system provides both chalenges and opportunities. It is important to eliminate the chalenges and keep the opportunities so that the implementation of online learning wi bring more positive impacts that support students' leaming success.

Alshameri, F. (2016). Traditional versus online learning in institutions of higher education: Minority business students' perceptions. Business and Management Research, 5(2), 3141.

Al-Qahtani, M., H. (2019). Teachers' and students' perceptions of virtual classes and the effectiveness of virtual classes in enhancing communication skils. Arab World English Journal, Special Issue: The Dynamics of EFL in Saudi Arabia. 223-240.

Anderson, T. (2011). The theory and practice of online learning $\left(5^{\text {th }} \mathrm{Ed}\right.$.). Edmonton: Athabasca University Press.

Appana, S. (2008). A review of benefits and limitations of online leaming in the context of the student, the instructor, and the tenured faculty. International Journal on E-Learning, ス1), 5-22.

Arkorful, V., \& Abaidoo, N. (2014). The role of elearning, the advantages and disadvantages of 


\section{P-ISSN 2622-9323 E-ISSN 2622-2213}

its adoption in higher education. International Journal of Education and Research, 2(12), 397-410.

Bączek, M., et, al. (2021). Students' perceptions of online learning during the COVID-19 pandemic: A survey study of Polish medical students. Medicine, 1007), 1-14.

Cohen, L., Manion, L., \& Morrison, K. (2000). Research methods in education (5 $5^{\text {th }} \mathrm{Ed}$.). London, England: Routledge Falmer.

Huber, S. G. \& Helm, C. (2020). Covid-19 and schooling: Evaluation, assessment, and accountability in times of crisis-reacting quickly to explore key issues for policy, practice, research with school barometer. Educational Assessment, Evaluation, and Accountability, 32: 237-270.

Jingyu, L (2014). Pros and cons: Web-based education. 2014 International Conference on Education, Management, and Computing (ICEMCT-14).

Rapanta, C., et., al. (2020). Online university teaching during and after the Covid-19 crisis: Refocusing teacher presence and learning activity. Post-digital Science and Education, 2: 923-945.

Sadeghi. (2019). A shift from classroom to distance karning: Advantages and Imitations. International Journal of Research in English Education 4(1), 80-88. 